\title{
Developing and Validating a Simulation Model for Counting and Classification of Vehicles
}

\author{
(Membangun dan Mengesahkan Model Simulasi untuk Pengiraan dan Pengelasan Kenderaan)
}

Ali Emad Jehad* \& Riza Atiq bin O.K. Rahmat

ABSTRACT

An algorithm system approach has been presented for extracting traffic data using video image processing. While an offline program focuses on extracting vehicles, tracking them and provides the vehicle count for a short period of time. It uses background subtraction, shadow removal, and pixel analysis for extracting moving objects. The results show that the algorithm is capable of counting 95\% of the vehicles due to some shaking in the video feed. These data have been analyzed by statistical regression to show the credibility of the results which been approved to be useful according to the value of $R$ Square and Significance F compared with the value of the observation method. Also, the classification of vehicles was performed using the improfile command in Matlab-Video Image Processing that computes the intensity values along a line or a multiline path in an image. The algorithm program was developed to detect vehicles in traffic videos and get the vehicle count for the small time period as an assistance tool for a researcher who seeks vehicle counting.

Keywords: Video image processing; algorithm system; Matlab; optical flow model; vehicles classification

ABSTRAK

Pendekatan sistem algoritma telah dikemukakan untuk mengekstrak data trafik menggunakan pemprosesan imej video. Walaupun program luar talian memberi tumpuan kepada mengekstrak kenderaan, menjejaki mereka dan menyediakan kiraan kenderaan untuk tempoh yang singkat. Ia menggunakan latar belakang penolakan, penyingkiran bayang-bayang, dan analisis pixel untuk mengeluarkan objek yang bergerak. Keputusan menunjukkan bahawa algoritma mampu mengira 95\% daripada kenderaan kerana beberapa berjabat dalam suapan video. Data-data ini telah dianalisis dengan statistik regresi menunjukkan kredibiliti keputusan yang telah diluluskan untuk menjadi berguna mengikut nilai $R$ Square dan Significance F berbanding dengan nilai kaedah pemerhatian. Juga klasifikasi kenderaan yang telah dilakukan dengan menggunakan arahan improfile dalam Matlab-Video Pemprosesan Imej yang akan mengira nilai keamatan sepanjang garis atau jalan yang Berbilang dalam imej. Program algoritma telah dibangunkan untuk mengesan kenderaan dalam video lalu lintas dan mendapatkan kiraan kenderaan untuk tempoh masa yang kecil sebagai alat bantuan bagi seorang penyelidik yang bertujuan kenderaan kiraan.

Kata kunci: Pemprosesan imej video; system algorithm; Matlab; model aliran optic; klasifikasi kenderaan

\section{INTRODUCTION}

Speed, flow, and density are macroscopic parameters for characterizing the traffic stream as a whole while headway and spacing are microscopic measures for distinguishing the individual vehicles (TRB 2010). High demands for computer algorithms and technological solutions have been raised due to computer vision techniques for traffic analysis and monitoring in a real-time mode (Mathew \& Rao 2007). Most convincing applications are in vehicle tracking, and the crucial issue is initiating a track automatically. In recent years, image processing has been applied to the field of traffic research with goals that include queue detection, incident detection, vehicle classification, and vehicle counting (Zehang et al. 2004) and (Dailey et al. 2000).
Many researchers have been trying to develop methods that can be applied in video-based traffic surveillance (Qian et al. 2013). Some of the applications of video base surveillance include vehicle tracking, counting the number of vehicles, calculating vehicle velocity, finding vehicle trajectory, classifying the vehicles, estimating the traffic density, finding the traffic flow, license plate recognition, etc. (Puan et al. 2014) and (Trivedi et al. 2007). Tracking is the process of measurements obtained from a target in order to maintain an estimate of its current state. A track is a state trajectory estimated from a set of measurements that have been associated with the same target. In tracking targets, there can be two major problems: an uncertainty associated with the measurements in addition to their accuracy, which 
is usually modeled by additive noise, and the uncertainty of the measurement origin - a measurement that is to be used in the tracking algorithm may not have originated from the target of interest (Morris \& Trivedi 2008).

\section{THEORETICAL WORK}

PIXEL ANALYSIS

Recognizing the absolute difference between the two respective images pixel-by-pixel with the present threshold is one of the basic method of change detection. A pixel, $\mathrm{I}(i, j)$, is considered as foreground pixel if the foreground difference, $\mathrm{d}(i, j)$ is:

$$
d(i, j)=\left[I_{t}(i, j)-I_{t-1}(i, j)\right]>T
$$

Where T denotes the preset threshold and It $(i, j)$ and It$1(i, j)$ are pixels at current and previous frames (Jianxin et al. 2003) and (Avery et al. 2004). Noted that the difference of two corresponding pixels in the subsequent frames is the main problem with this simple approach. The absolute difference could less than the threshold if the pixel under consideration lacks texture and is part of the moving object, this pixel will be considered as a background pixel. Also, random camera noise can further confuse the decision to be made.

To overcome this problem a background image is constructed using several frames from the video. Now, instead of comparing with the previous frame, the current frame is compared with the background image.

$$
d(i, j)=\left[l_{t}(i, j)-B(i, j)\right]>T
$$

For background image construction, the histogram is constructed at each pixel location. A pixel can have a value between (0) and (255). Frames with same pixel value are grouped together to make the histogram. Since the foreground region will be covered by the moving vehicles with different colors it can be assumed that the pixel value that occurs most frequently in the histogram is the background pixel. This way a background image is generated.

\section{SHADOW REMOVAL}

Removing cast shadow is a proposed edge-based algorithm by (Xiao et al. 2007). They based their algorithm on three observations. They found after generating edges on foreground images that:

1. The cast shadows present sharp edges because the illumination source is far from the objects;

2. The vehicle has significant edges; however the corresponding shadow is generally edgeless;

3. The edge of cast shadow fastens on the boundary region of the moving foreground mask.
According to (Porikli \& Thornton 2005) assumption method which stated that: "shadow decreases the luminance and changes the saturation, yet it does not affect the hue". Figure (1) shows that the color vector $I(p)$ was pointed to the background vector $B(p)$ to get the luminance change $h$.

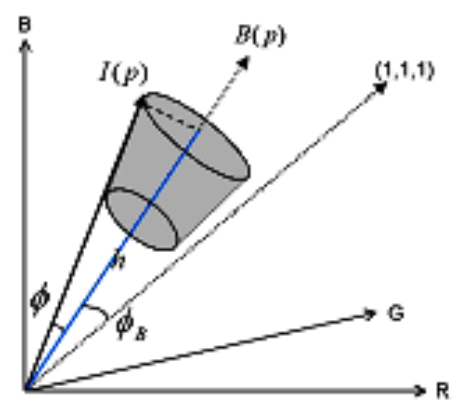

FIGURE 1. Weak shadow is defined as a conic volume around the corresponding

$$
h=[I(p)] \cos \varnothing
$$

Where is the angle between $B(p)$ and $I(p)$. Another angle is computed between background vector and $(1,1,1)$ vector. They, further, define luminance ratio as $\mathrm{r}=[I(p)]$ $h$. Pixels satisfying the following criteria are considered as shadow pixel.

$$
\emptyset<\min \left(\emptyset_{B}, \emptyset_{o}\right), \quad r_{1}<r<r_{2}
$$

Where is the maximum angle separation, determines maximum allowed darkness and brightness respectively. In this research, this approach is used to eliminate all shadow pixels.

\section{VEHICLE TRACKING}

The distance between all vehicle images was used by (Atkociunas et al. 2005) using coordinates of their centre to find the tracking vehicles in the subsequent frames. Firstly, the marked the geometric centres of each vehicle which calculated as followed:

$$
X_{c}=\frac{\sum x_{j}}{n}, Y_{c}=\frac{\sum y_{j}}{n}
$$

Where and are vehicle center coordinates and $\mathrm{Xj}$ and $\mathrm{Yj}$ are the coordinates of pixel lying within the boundary of the target vehicle. Their assumption on tracking vehicles was "displacement of the image centre of the observed vehicle in two neighboring frames is less than the distance between it and another vehicle's centers in the same or neighboring frames". The calculation distances between all vehicles in frame $n$ and all vehicles in frame $(n+1)$ using coordinates (,) of their centers is to find the tracking vehicle:

$$
d_{k}=\sqrt{\left(x_{k}-x_{c}\right)^{2}+\left(y_{k}-y_{c}\right)^{2}}
$$




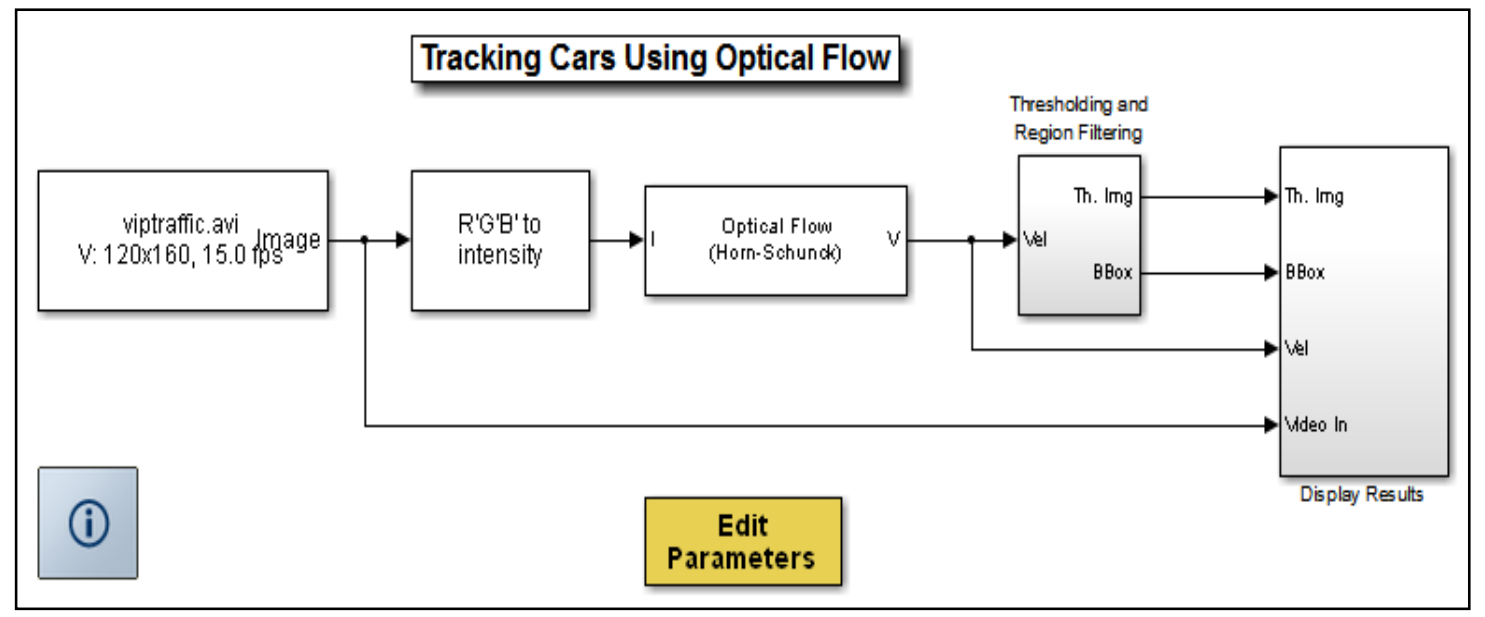

FIGURE 2. Tracking cars using optical flow model.

Source: http://www.mathworks.com

Finding the minimum of gives the tracking vehicle. Applying this method to all the vehicles presents in the current image will keep them tracked.

\section{METHODOLOGY}

Optical flow estimation model was used to estimate the motion vectors in each frame of the video sequence. Binary feature images were produced by Thresholding and performing morphological closing on the motion vectors model. The model locates the cars in each binary feature image using the Blob Analysis block (Figure 2).

The "From Multimedia File block" reads audio samples, video frames, or both from a multimedia file. The block imports data from the file into a Simulink model while The "Color Space Conversion block" converts color information between color spaces. The conversion from the R'B'G' color space to intensity is defined by the following equation:

$$
\text { intensity }=\left[\begin{array}{lll}
0.299 & 0.587 & 0.114
\end{array}\right]\left[\begin{array}{l}
R^{\prime} \\
G^{\prime} \\
B^{\prime}
\end{array}\right]
$$

The "Optical Flow block" estimates the direction and speed of object motion from one image to another or from one video frame to another using either the Horn-Schunck or the Lucas-Kanade method. To compute the optical flow between two images, you must solve the following optical flow constraint equation:

$$
I_{x} u+I_{y} v+I_{t}=0
$$

The "Thresholding and Region Filtering Block" represents a series of subsystems:

1. Provide an input port for a subsystem or model

2. Represents mathematical functions including logarithmic, exponential, power, and modulus functions.

3. Compute the mean value along the specified dimension of the input or across time (running mean).

4. Uses the Neighborhood size parameter to specify the size of the neighborhood.

5. Perform morphological closing on an intensity or binary image.

Figure (3) shows the subsystem block of Thresholding and Region Filtering model.

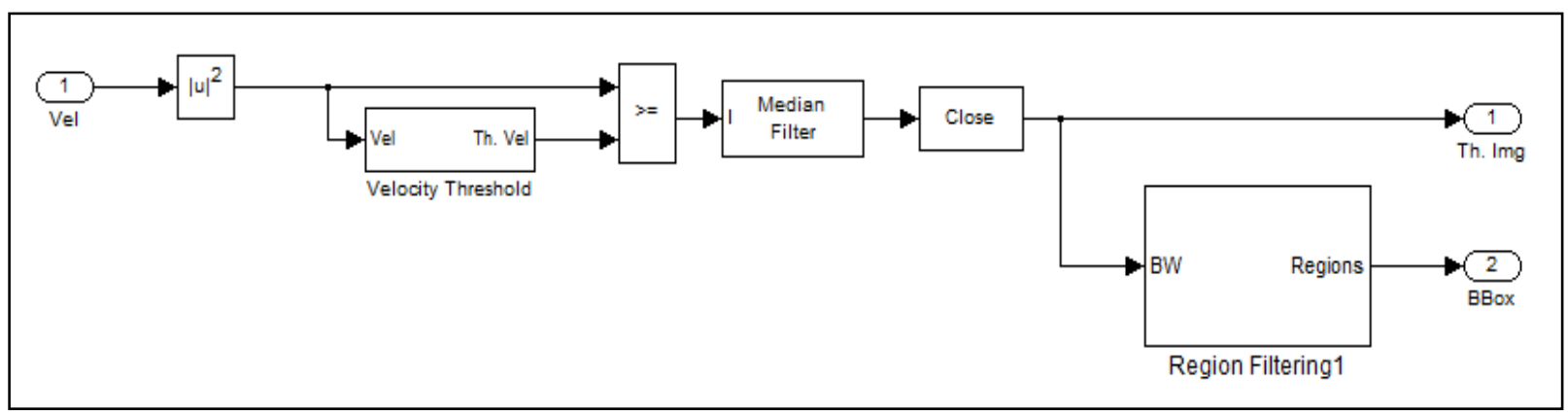

FIGURE 3. Thresholding and Region Filtering model. Source: http://www.mathworks.com 
Finally, Draw Shape block was used to draw a green rectangle around the cars that pass beneath the white line. The following figure shows four windows which represent the input screen along with the vector analysis for the vehicles beside the thresholding analysis to conclude with the result window.

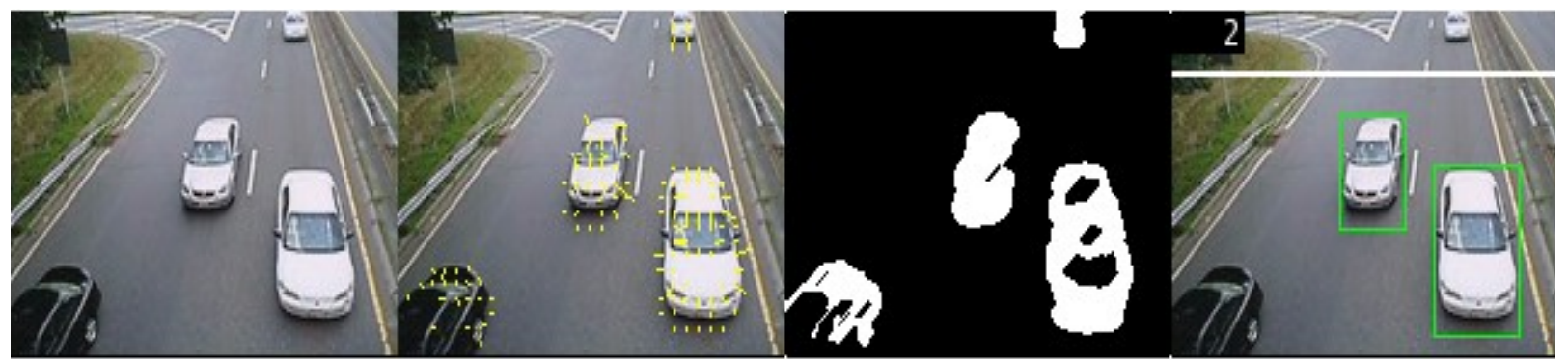

FIGURE 4. Display Results Windows.

Source: http://www.mathworks.com

It is necessary to select a high level of traffic flow sites that give realistic results in order to be analyzed statistically. To collect corrected and sufficient data that satisfy the requirements of statistical calculations and representations. Selected sites should satisfy the followings:

1. The existence of an accessible vantage point allows for data collection to be made without effect on the observed traffic behavior.

2. Vehicle flow varies over the times of the day.

3. Range in the percentage of vehicle movement types and traffic compositions are to be considered.

\section{DATA COLLECTION}

Along the daytime of work days (7:30 - 10:30 am), surveys were made to three highway sections for the two opposite directions along LEBUHRAYA KAJANG SILK divided multilane highway crossing KAJANG city, MALAYSIA. Based on surveys, divided multilane highway sections were selected since these were found to satisfy the objectives and specifications of data collection. Fifteen minutes have been adopted as a period time along the specified working time which leads us to (12) time-segments per section per direction. As a total, (72) time-segments have been recorded for all sections per directions.

The recorded data were abstracted from video films with the aid of computer program called MATLAB ${ }^{\circledR}$ program. Developed by MathWorks, MATLAB ${ }^{\circ}$ allows matrix manipulations, plotting of functions and data, implementation of algorithms and creation of user interfaces.

Unnecessary objects have been removed from the video sections using the Shadow Removal technique based on the edge generation algorithm for foreground object's images and omitting the background's disruption by changing the saturation level.

\section{DATA ANALYSIS AND RESULTS}

The procedures which presented in this section are performing a multiple regression analysis between observed and programmed counting based on the survey to know the credibility of programs counting instead of using the observed one, then classify the vehicles by using video image processing technique.

\section{MULTIPLE REGRESSION ANALYSIS}

A Multiple Regression Analysis is performed when there are two different variables and must compare the differences between them to save the significant. To do so, firstly, we must state the dependent and independent variables for the analysis. Linear regression models with more than one independent variable are referred to as multiple linear models, as opposed to simple linear models with one independent variable (Orlov 1996). Equation (9) shows the general formula of the classification of regression models with mathematical expressions:

$$
y=b_{o}+b_{1} x_{1}+b_{2} x_{2}+\ldots b_{p} x_{p}
$$

Where:

$\mathrm{y}=$ dependent variable (predicted by a regression model)

bo $=$ intercept (or constant)

$b i=(i=1,2, \ldots p)-i$ th coefficient corresponding to $x i$

$x i=(i=1,2, \ldots p)-i$ ith independent variable from total set of $p$ variables

$\mathrm{p}=$ number of independent variables (number of coefficients)

$\mathrm{n}=$ number of observations (experimental data points)

The two variables in this project are observed and programmed counting based on the survey. First, we must satisfy that Hypothesized Mean Differences is (0) which means there are no differences between two groups and 
Alpha is (0.05) which also means the Standard Deviation for the groups. Then analyze the two groups by "Regression". Table (1) and Figure (5) show analyzing results for observing and programmed counting for Section A (7:30 10:30) - North Bound (NB). The results show that the value of $R$ Square is (0.9971). The second piece of information is the value of Significance $F$ is $(5.41 \mathrm{E}-14)$ which is less than our Alpha value of (0.05) which mean that we can't reject the null hypothesis. Also, the Intercept Coefficient is $(-8.3294)$

TABLE 1. Summary output for section A (NB)

\begin{tabular}{ccccc}
\hline Time & Observation & Program & \multicolumn{2}{c}{ Regression Statistics } \\
\hline $7: 30$ & 1753 & 1784 & Multiple R & 0.998529 \\
$7: 45$ & 2641 & 2677 & R Square & 0.99706 \\
$8: 00$ & 2258 & 2235 & Adjusted R Square & 0.996766 \\
$8: 15$ & 2495 & 2441 & Standard Error & 35.15832 \\
$8: 30$ & 1632 & 1682 & Observations & 12 \\
$8: 45$ & 1361 & 1383 & Significance F & $5.41 \mathrm{E}-14$ \\
$9: 00$ & 1143 & 1112 & Intercept Coefficients & -8.32947 \\
$9: 15$ & 899 & 915 & observation Coefficients & 1.004157 \\
$9: 30$ & 1149 & 1124 & & \\
$9: 45$ & 964 & 932 & & \\
$10: 00$ & 1047 & 1020 & & \\
$10: 15$ & 1171 & 1185 & & \\
\end{tabular}

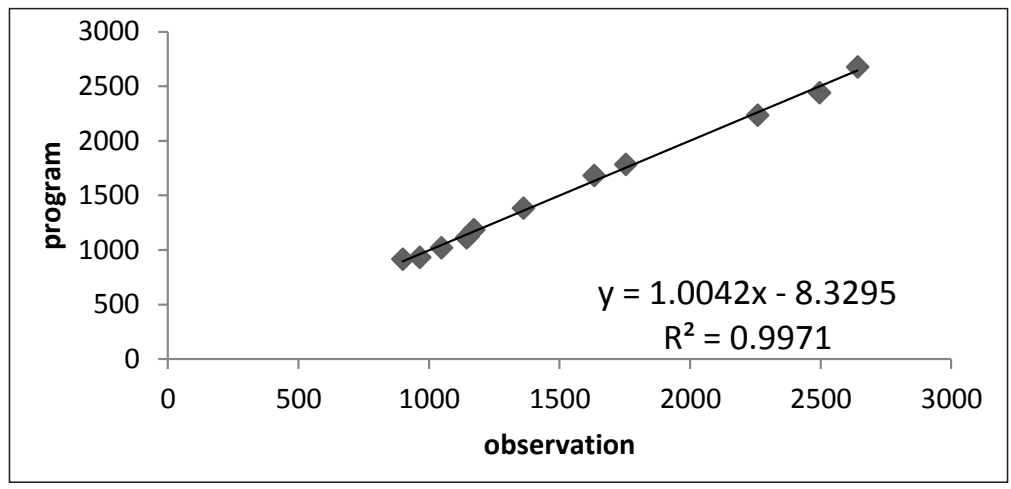

FIGURE 5. Line fit plot for program and observation.

\section{CLASSIFICATION OF VEHICLES}

Improfile code was used to do vehicles classification in Matlab-Video Image Processing that computes the intensity values along a line or a multiline path in an image. Improfile selects equally spaced points along a specified path, and then use interpolation to find the intensity value for each point. Improfile works with grayscale intensity images and RGB images. Figures (6) show the variation of RGB images and a pixel-value cross-section along line segments for long and short vehicles snapshot images of a video feed.

Thus, finding from this study suggests that algorithm model can estimate the number of passing vehicles from recorded video segments using optical flow model which represent the actual values of the real number of vehicles according to the multiple regression analysis. The result of
$R$-Square shows that we can't reject the result of the model despite the minor error of reading between the observation and program variables which can be accepted as there is no significance mean differences. Classification modelling has been made to classify the vehicles as a preventing tool of miscounting the small vehicles like motorcycles by scanning the intensity of the longitudinal line of the vehicle across pixels.

Enough data was gathered (72 time-segments) across the specified sections to show the credibility of the algorithm model against the real counting which takes a long time and much effort to collect during bad weather. Therefore, if the algorithm model is to be applied, resulting values need to be adjusted according to the methodology section. 

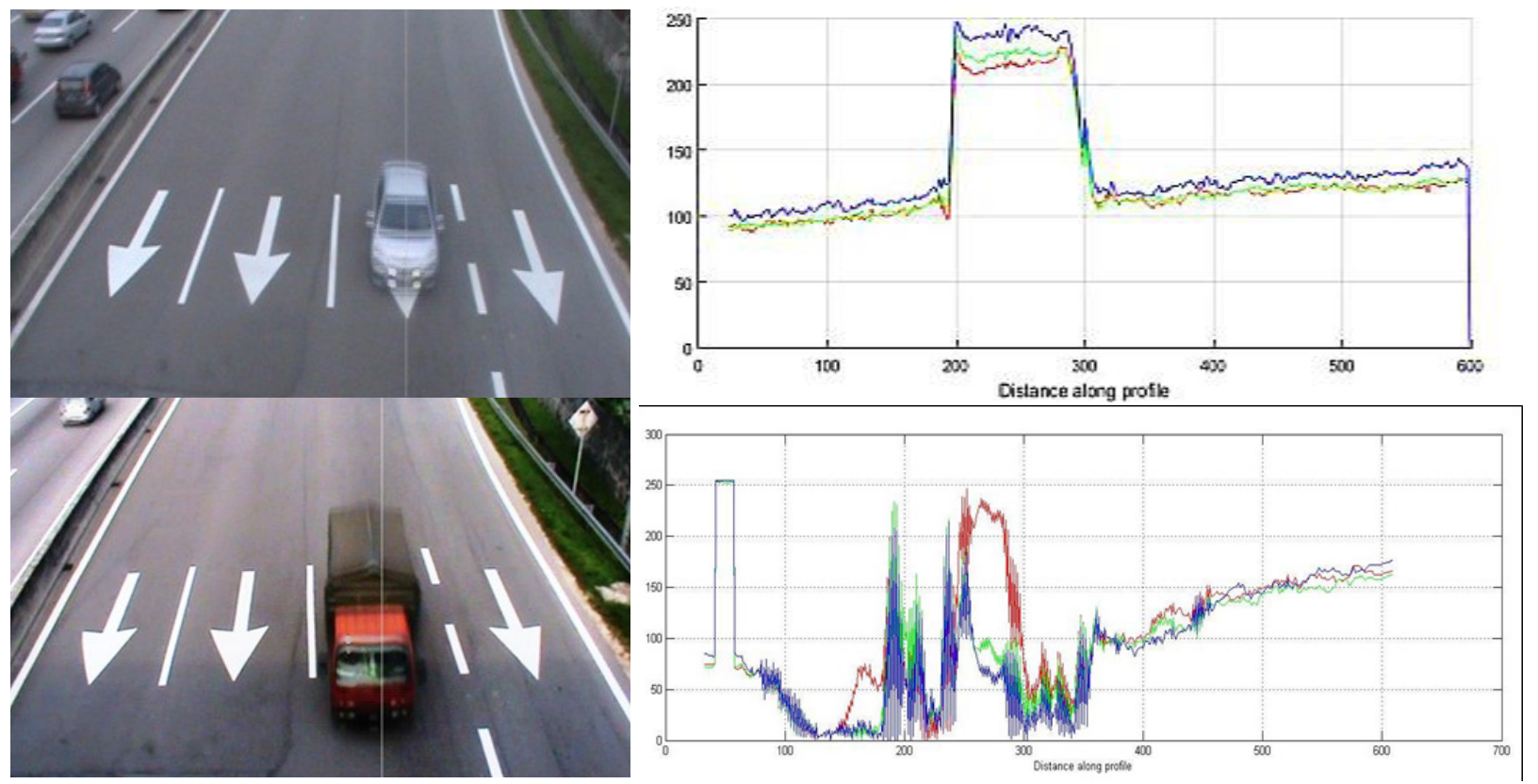

FIGURE 6. RGB snapshot image for long and short vehicles and their Pixel-value cross-sections along line segments

CONCLUSION

In this paper, an algorithm model was developed and implemented by MATLAB to detect vehicles in traffic videos and get the vehicle count for the small time period by a simple camcorder. The background extracted, with an assumption that camera position is still and stable. Since the extraction process was for a small duration, it was assumed that there is no sudden change in illumination (day time). With that assumption, almost $95 \%$ of the vehicles were detected correctly. During shadow removal process, pixel analysis, some of the vehicles (especially motorcycle) were miscounted due to the appearance of heavy vehicles in front of the motorcycles. This led us to a conventional linear regression analysis with underestimates the regression coefficient for NB sections and overestimates the regression coefficient for South Bound (SB) sections. The purpose of this study was to detect and count the number of vehicles, so an algorithm for vehicle tracking is used instead of tracking the vehicles by observation. This algorithm program was tested successfully and the results were found close to the actual numbers.

\section{ACKNOWLEDGMENTS}

We would like to show our gratitude to all postgraduate students of UKM for their help, friendship, and creating a pleasant working environment throughout our years in UKM.

\section{REFERENCES}

Atkociunas, E., Blake, R., Juozapavicius, A. \& Kazimianec, M. 2005. Image processing in road traffic analysis. Nonlinear Analysis: Modelling and Control 10(4): 315-332.

Avery, R. P., Wang, Y. \& Scott Rutherford, G. 2004. Length-based vehicle classification using images from uncalibrated video cameras. Intelligent Transportation Systems, 2004. Proceedings. The 7th International IEEE Conference on. pp. 737-742.

Dailey, D. J., Cathey, F. W. \& Pumrin, S. 2000. An algorithm to estimate mean traffic speed using uncalibrated cameras. Intelligent Transportation Systems, IEEE Transactions on 1(2): 98-107.

Jianxin, W., Getain, Y., Mark, P., Michael, F. \& John A. 2003. Robust and self- adaptive background extraction in video object change detection. Applications of Digital Image Processing 26. 5203: 142-147.

Mathew, T., V. \& Rao., K., V., K. 2007. Introduction to Transportation Engineering. Fundamental Parameters of Traffic Flow. 30.1-30.8. NPTEL Web Course.

MathWorks. 2006. Tracking cars using optical flow (online) http://www.mathworks.com/examples/simulinkcomputer-vision/712-tracking-cars-using-optical-flow.

Morris, B. T. \& Trivedi, M. M. 2008. Learning, modeling, and classification of vehicle track patterns from live video. Intelligent Transportation Systems, IEEE Transactions on 9(3): 425-437. 
Orlov, M., L. 1996. Multiple Linear Regression Analysis Using Microsoft Excel. Chemistry Department, Oregon State University.

Porikli, F. \& Thornton, J. 2005. Shadow flow: a recursive method to learn moving cast shadows. Computer Vision, 2005. ICCV 2005. Tenth IEEE International Conference 1: 891-898.

Puan, O. C., Ibrahim, M. N. \& Abdurrahman, U. T. 2014. Application of moving car observer method for measuring free flow speed on two-lane highways. Jurnal Teknologi (Sciences \& Engineering) 69(6): 1519.

Qian, Z., Shi, H., Yang, J. \& Duan, L. 2013. Video-based multiclass vehicle detection and tracking. IJCSI International Journal of Computer Science Issues 10(1): 570-578.

TRB. 2010. Highway Capacity Manual. 5th edition. Washington, D.C.: National Research Council.

Trivedi, M. M., Gandhi, T. \& McCall, J. 2007. Looking-In and Looking-Out of a Vehicle: Computer-Vision-Based Enhanced Vehicle Safety. Intelligent Transportation Systems, IEEE Transactions on 8(1): 108-120.
Xiao, M., Han, C \& Zhang, L. 2007. Moving shadow detection and removal for traffic sequences. International Journal of Automation and Computing 4(1): 38-46.

Zehang, S., Bebis, G. \& Miller, R. 2004. On-road vehicle detection using optical sensors: a review. Intelligent Transportation Systems. Proceedings. The 7th International IEEE Conference on. pp. 585-590.

\section{Ali Emad Jehad* \\ Riza Atiq bin O.K. Rahmat}

Department of Civil \& Structural Engineering

Faculty of Engineering \& Built Environment

Universiti Kebangsaan Malaysia,

43600 Bangi, Malaysia

*Corresponding author; email: aliemad87@gmail.com

Received Date: $28^{\text {th }}$ January 2016

Accepted Date: $21^{\text {st }}$ April 2016 